\title{
ANALISIS IMPLEMENTASI HUKUM DALAM PERSFEKTIF PERILAKU MASYARAKAT
}

\author{
Azmi Siradjuddin \\ IAIN METRO \\ E-mail : azmisiradjuddin1965@gmail.com
}

\begin{abstract}
Implementation of law is the most useful for a nation and a state in a country thas has powerfull of protecting its people to do better and the best in their attitudes and behaviors when they live and do everything in order to have good connection among society in the social climate. Having understood in law is one thing to do every action based on the law either God's law or state's law. The functions of law are to control the human'action, to change the situation to better situation and to give justice and prosperious for people in a country. No one to disturb and make noisy till one has good condition by obeying law that is created by God and Human (Indonesian Legislative Assembly in Indonesian Contects).

By knowing and obeying law, person will get safety when they go and live. Law means regulations that manage human to surrender to that law that is created by God and Human (state). In Islamic law, law is consist of five principles, wajib (compulsory), not allowed (haram), allowed (sunnah), hate (makruh), and mubah. All those fungtions of the law always protect us/human from demage, poverty, and crime. Law is as a soul for every human and too law is as a foundation for a country to protect its people from demage, povery, and crime. Law gives freedom to do by the condition obey to the law. Who breaks the law must be funished either by low funishment or hard funishment till go to a jail to be responsible what they have done.
\end{abstract}

Key word: Implementation, law, persfektive, human's behaviors in society 


\section{A. Pendahuluan}

Arti implementasi menurut KBBI adalah pelaksanaan atau penerapan ${ }^{1}$. Pelaksanaan atau penerapan hokum merupakan suatu keniscahayaan di manapun dan kapanpun. Sifat yang paling mendasar dalam konteks hukum adalah memaksa (compulsory) ${ }^{2}$, dan di dalam istilah hokum Islam adalah wajib dan ditambah dengan istilah mengikat (incompulsary) atau sunnah dalam istilah hukum Islam³ . Arti hukum itu sendiri adalah berpariasi dan definisi hukum itu sendiri belum ada kesepakatan oleh para ahli hukum atau pemerhati di bidang hukum, karena hukum itu berkembang dan menyelimuti di dalam setiap bidang kehidupan ${ }^{4}$. Kalau seseorang bertanya kapan/sejak kapan hukum itu ada? Berdasarkan sejarah Islam dan literatur hukum Islam bahwa hukum itu sudah ada sejak tragedi di surga, yaitu tragedi pertama ketika Allah berfirman kepada malaikat, "Aku (Allah) hendak menciptakan di muka bumi seorang kholifah ${ }^{5}$. Kholifah di sini adalah manusia, yaitu Adam a.s. Maka apa yang terjadi? Di dalam alQur'an, Allah memerintahkan Malaikat dan Iblis untuk sujud (hormat) kepada Adam a.s. Maka apa yang terjadi? Para malaikat sujud dan Iblis mengingkari perintah Allah untuk tidak sujud ${ }^{6}$. Tragedi kedua, Allah melarang Adam dan Hawa untuk mendekati buah kuldi. Maka keduanya melanggar dengan mendekati dan memakan buah kuldi tersebut. Maka apa yang terjadi? Allah murka kepada Adam dan Hawa. Tragedi pertama, Allah murka terhadap Iblis. Lalu, Allah memerintahkan kepada Adam/Hawa dan Iblis untuk meninggalkan surga dan turun ke muka bumi. Sejak itulah menurut penulis jurnal ini, mulai adanya hokum terhadap penduduk surga.

Berdasarkan phenomena dua tragedi tersebut di atas, maka mulailah ruang kehidupan di muka bumi antara dua mahkluk, yaitu manusia dan Iblis. Sejak itulah hokum mulai berlaku di muka bumi. Iblis berjanji kepada Allah bahwa Iblis akan mengggoda keturunan Adam dan Hawa. Ucapan Iblis/dendam Iblis dibuktikan dengan tergodanya anak Adam dan Hawa, yaitu, terbunuhnya Habil oleh Qobil. Allah memerintahkan Adam untuk kedua putranya, yaitu Qobil dan Habil untuk melakukan perbuatan hokum. Apa itu? Agar kedua nya mensodaqohkan hasil pekerjaannya, Qobil adalah seorang petani yang berhasil dengan hasil panennya berupa

\footnotetext{
${ }^{1}$ Lihat Kamus Besar Bahasa Indonesia, h. 125.

${ }^{2}$ Bagir Manan, "Penelitian di Bidang Hukum", Jurnal Hukum Puslitbangkum, edisi Perdana, Pusat Penelitian dan Perkembangan Ilmu HukumLembaga Penelitian Universitas Padjajaran, Bandung, 1999.

${ }^{3}$ Wael b Hallaq, Sejarah Teori Hukum Islam, (Jakarta: Grafindo, 2000), h. 267.

${ }^{4}$ Soerjono Soekanto dan Purnadi P, Perihal Kaidah Hukum, (Bandung: Citra Adytia Bakti, 1993), h. 88. ${ }^{5}$ Departemen Agama RI, Quran dan Terjemahannya, (Bandung: 2002), h. 67-68. Lihat al-Baqorah: 30. ${ }^{6}$ Ibid., h. 135.
} 
tanaman/sayuran, dan Habil adalah seorang peternak yang berhasil dalam peternakannya. Maka keduanya diperintahkan untuk mengeluarkan sebagian rezeki yang Allah telah menganugrahkan kepada keduanya. Namun, apa yang terjadi? Habil memberikan ternak dombanya yang paling bagus dari semua dombanya dan Qobil memberikan hasil pertaniannya berupa sayuran-sayuran yang paling jelek. Maka Allah menerima sedekah Habil dan menolak sedekah Qobil. Juga, Allah memerintahkan Adam untuk menikahkan kedua putranya dengan kedua putrinya dengan cara kawin silang. Qobil menikah dengan adik Habil yang memiliki wajah tidak menarik dan Habil menikah dengan adik Qobil yang cantik dan menarik. Namun, Qobil tidak menerima seruan ayahnya. Singkat cerita; Qobil membunuh Habil. Sejak tragedi itulah merupakan pembunuhan pertama sesama manusia. Akhirnya Iblis memenangkan dan menepati janjinya untuk menggoda anak keturunan Adam dan Hawa sampai datangnya hari kiamat. Di sinilah, kita berbicara hokum. Berarti hokum itu apa? Menurut penulis sebagai dosen di mata kuliah sosiologi hokum, hokum berarti seperangkat aturan-aturan baik yang dibuat oleh Tuhan (agama) maupun oleh manusia (Negara) yang mengatur perilaku-perilaku manusia sejak balig hingga kematiannya, agar manusia dapat berjalan sesuai aturan-aturan hokum tersebut, di mana hokum yang sifatnya memaksa dan mengikat. Sementara hokum dalam konteks Islam, yaitu seperangkat aturan-aturan yang berupa al-ahkam al-khomsah (hokum yang lima), yaitu, wajib, haram, sunnah, makruh dan mubah.

Hukum mengatur perilaku manusia sejak balig sampai kematiannya. Secara naluri manusia satu sisi senang diatur oleh suatu aturan dan satu sisa tidak senang diatur oleh suatu aturan, khususnya ketika terjadinya interaksi yang terjadi bila seorang individu berhubungan dengan orang lain. Di dalam ilmu psikologi sosial bahwa fokus utama psikologi sosial adalah pada pemahaman mengenai bagaimana dan mengapa individu berperilaku, berpikir dan memiliki perasaan tertentu di dalam konteks situasi sosial7, artinya ketika terjadi interaksi sosial, baik individu maupun kelompok saling memikirkan apa yang akan terjadi dan siapkah saya menghadapinya termasuk di dalam konteks hukum sekalipun.

Berbicara konteks huokum, maka menurut penulis, kita harus berbicara tentang pemberdayaan hukum. Hukum selain diterapkan, juga hukum harus diberdayakan terhadap masyarakat luas. Pemberdayaan adalah upaya peningkatan kemampuan di dalam mencapai penguatan diri untuk meraih sesuatu yang lebih baik khususnya di bidang hukum.

\footnotetext{
${ }^{7}$ Yeni Widyastuti, Psikilogi Sosial,(Yogyakarta: Graha Ilmu, 2014), Cet I, h. 2.
} 
Pemberdayaan akan melahirkan kemandirian, baik kemandirian berpikir, bersikap, dan bertindak yang bermuara kepada pencapaian harapan hidup yang lebih baik. Pemberdayaan menekankan bahwa seseorang memperoleh keterampilan, pengetahuan, dan kekuasaan yang cukup untuk mempengaruhi kehidupannya dan kehidupan orang lain yang menjadi perhatiannya $^{8}$.

Menurut teori Stufenbau oleh Hans Kelsen', bahwa hukum itu seperti anak tangga, dari bawah ke atas. Menurut Hans Kelsen bahwa hokum yang di bawah/paling bawah tidak boleh bertentangan dengan hukum yang di atasnya. Demikian pula, hukum di dalam konteks hukum Islam, hukum yang berada di bawahnya tidak boleh bertentangan dengan hukum yang lebih di atasnya ${ }^{10}$. Hadis nabi tidak boleh bertentang dengan al-Quran, Namun, Hadis nabi yang berupa perkataan, perbuatan dan pernyataan nabi adalah wahyu Allah. Wa ma yantiqu anil hawa In huwa Illa wahyun yuha.

Di dalam kajian sosiologi hukum ada istilah "grundnorm". Grundnorm artinya normanorma dasar. Definisinya adalah dasar-dasar sosial daripada hukum. Tujuan dan maksud grundnorm adalah bahwa dasar perilaku-perilaku manusia baik individu maupun kelompok di manapun dan kapanpun mereka (individu/kelompok) berada, maka dasar perilaku-perilaku mereka harus didasari oleh dua aturan hukum, yaitu hukum Tuhan/Allah (agama) maupun hukum Negara (hukup positif berupa undang-undang) ${ }^{11}$. Oleh karena itu, perilaku-perilaku manusia tadi harus dikontrol/dikendalikan oleh aturan hukum yang baku/berlaku.

Manusia sebagai makhluk sosial harus berinteraksi dengan satu sama lainnya. Interaksi sosial terebut harus sesuai dengan aturan hukum yang berlaku. Ketika seorang muslim mendengar azan, maka dia seharusnya memenuhi panggilan tersebut untuk segera bergegas ke masjid/musholla. Saling tegur sapa dengan mengucapkan 'assalamu'alaikum'. Ketika seseorang mengendarai kendaraan, maka dia harus membawa STNK dan SIM serta mengikuti aturan lalulintas untuk tidak melanggar aturan lalu lintas berupa traffic light, kebut-kebutan, dan sebagainya. Inilah bentuk implementasi hukum terhadap perilaku-perilaku masyarakat baik individu maupun kelompok di dalam kondisi apapun. Sejauh mana efektifitas perilaku hukum masyarakat di dalam sebuah Negara berdaulat dan di dalam kancah pergaulan manusia itu sendiri baik secara lokal, nasional, dan internasional?.

\footnotetext{
${ }^{8}$ Edi Suharto, Membangun Masyarakat Memperdayakan Masyarakat, h. 58-59.

${ }^{9}$ Azmi Siradjuddin, Sosiologi Hukum, (Metro: Marboro Printing, 2016), h. 25.

${ }^{10}$ Abu Yasid, Nalar dan Wahyu, (Jakarta: Penerbit Erlangga, 2007), h. 130.

${ }^{11}$ Azmi Siradjuddin, Sosiologi ..., h. 27.
} 
Hukum adalah panglima dan sekaligus sebagai soko guru bagi manusia yang memiliki peradaban yang tinggi dan harmonisasi antara hukum dan manusia harus dilestarikan dan dijaga terus menerus demi terciptanya masyarakat yang adil dan makmur sesuai dengan lima sila khususnya sila kedua dan kelima dari Pancasila (five principles) dan Pancasila adalah ideologi bangsa Indonesia yang eksistensinya harus dipertahankan dan dijaga serta lima sila tersebut merupakan pengayom bagi masyarakat Indonesia yang majemuk, multi etnis, multi bahasa, agama, dan multi perilaku. Dengan Pancasila sebagai (grundnorm) teratas, dan diikuti Undang-Undang Dasar 1945 (UUD 45) keduanya merupakan dasar-dasar perilaku bangsa Indonesia secara menyeluruh di wilayah NKRI. Mayoritas bangsa Indonesia adalah beragama Islam, tentu masyarakat muslim Indonesia wajib menjunjung tinggi ideologi bangsa Indonesia, yaitu Pancasila dan UUD 45, namun, khususnya umat Islam selain menjunjung tinggi Pancasila dan UUD 45 sebagai perilaku horizontal di dalam sebuah Negara yang berdaulat, juga umat Islam wajib tunduk kepada kedua sumber agama Islam/ajaran Islam, yaitu al-Quran dan Hadis nabi yang berupa perkataan, perbuatan dan pernyataan dan sekaligus ketiganya sebagai sunnah-sunnah nabi Muhammad SAW yang harus (sunnah) dipatuhi oleh umat Islam jika mereka ingin selamat dari ancaman siksa Allah baik di dunia maupun di akhirat kelak. "Jika kalian berselisih di dalam satu hal perkara, maka kembalikan perkara tersebut kepada Allah dan RasulNya, serta ulil amri (pihak ekskutif/umara dan ulama")12. Jadi, Pancasila, UUD 45 dan al-Quran serta Sunnah-sunnah nabi adalah grundnorm bagi bangsa Indonesia yang beragama Islam.

\section{B. Pembahasan.}

Untuk memahami dan mengetahui secara komprihensif tentang implementasi hukum terhadap perilaku-perilaku hukum masyarakat, mau tidak mau kita harus mempelajari sosiologi hukum. Dengan memahami tujuan sosiologi hukum, maka seseorang yang ingin mengetahui bagaimana implementasi hukum di dalam persfektif perilaku masyarakat, maka dia harus mengetahui apa tujuan sosiologi hukum. Di dalam kajian Sosiologi Hukum, diketahui bahwa Sosiologi hukum adalah ilmu yang mempelajari hubungan timbal balik antara hukum dengan gejala-gejala sosial lainnya secara empiris-analitis.

\footnotetext{
${ }^{12}$ Q S. An-Nisa, ayat 59.
} 
Berdasarkan definisi tersebut di atas, hukum atau aturan-aturan baik yang dibuat oleh Tuhan maupun Negara memberikan dampak berupa kebaikan atau kejenuhan. Jika hukum selalu dipublikasikan ke dalam sendi-sendi kehidupan masyarakat dengan melalui penyuluhan-penyuluhan, seminar-seminar, kajian-kajian, ceramah-ceramah, nasehat-nasehat, dan sebagainya, maka hukum akan memberikan ma'na dan proses pembelajaran yang signifikan dan tentunya penerapan hukum baik hukum Tuhan (hukum agama) maupun hukum Negara (hukum positif) akan memberikan positive impact (dampak positif) bagi gejalagejala sosial atau perilaku-perilaku masyarakat ${ }^{13}$. Oleh karena itu, para stakerholders baik di pemerintahan, lembaga-lembaga sosial non pemerintah, maupun organisasi-organisasi masyarakat (ormas) harus bekerjasama dengan pihak-pihak otoritas hukum seperti, lembagalembaga hukum, MUI, tokoh-tokoh agama, Ulama, ustad-ustad, cendikiawan muslim untuk terus menerus mensyiarkan materi-materi hukum kepada masyarakat luas.

\section{Menurut Brade Meyer}

- Sociology af the law - Menjadikan hukum sebagai alat pusat penelitian secara sosiologis yakni sama halnya bagaimana sosiologi meneliti suatu kelompok kecil lainnya. Tujuan penelitian adalah selain untuk menggambarkan betapa penting arti hukum bagi masyarakat luas juga untuk menggambarkan proses internalnya hukum ${ }^{14}$.

Pemahaman tersebut di atas adalah bahwa hukum harus selalu dikaji dan diteliti secara seksama dan komprehensif, apakah hukum membawa kemaslahatan atau kejenuhan. Jika hukum membawa kemasalahatan bagi masyarakat secara luas, maka hukum memiliki daya tarik dan hukum seperti ini harus dijaga dan dilestarikan sebagai paradigma yang memiliki efek-efek hukum yang baik, karenanya hukum seperti ini harus menjadi pedoman bagi kehidupan baik bermasyarakat maupun berbangsa dan bernegara. Juga, penelitian secara sosiologis harus digalakkan dan dilestarikan agar mendapat sesuatu yang membawa kemantapan dan kematangan di dalam berhukum.

- Sociology in the law - Untuk memudahkan fungsi hukumnya, pelaksanaan fungsi hukum dengan dibantu oleh pengetahuan atau ilmu sosial pada alat-alat hukumnya.

\footnotetext{
${ }^{13}$ Satjipto Rahardjo, Hukum Dalam Jagad Ketertiban, (Jakarta: Uki Press), h. 45.

${ }^{14}$ Ibid., h. 50.
} 
Pernyataan tersebut di atas adalah bahwa hukum akan berfungsi di masyarakat jika sarana-sarananya terpenuhi seperti, adanya aturan-aturan hukum yang jelas dan komprehensif (tidak memihak), adanya fasilitas hokum berupa, gedung, alat-alat peraga hokum, seperti alat tes kebenaran/kebohongan seseorang yang dianggap bersalah atau benar, adanya penegak hukum yang saling bersinergi, mereka adalah polisi, jaksa, pengacara, dan hakim, dan adanya masyarakat yang siap menerima aturan-aturan hukum ${ }^{15}$.

- Gejala sosial lainnya - Sosiologi bukan hanya mempersoalkan penelitian secara normatif (dassollen) tetapi juga mempersoalkan analisis-analisis normatif di dalam rangka efektifitas hukum agar tujan kepastian hukum dapat tercapai.

Pernyataan tersebut di atas adalah bahwa ilmu sosiologi tidak hanya meneilti masalah-masalah normative, seperti bab-bab hukum, pasal-pasal hukum, dan ayatayat/butir-butir hukum saja (dassolen), tetapi juga ilmu sosiologi meneliti bagaimana proses-proses analisis terhadap gejala normative di atas, dengan harapan tercapainya efektifitas hukum dan kepastian hukum yang akhirnya terwujudnya perubahan sosial baik secara mendasar maupun utuh/holistik.

\section{Konsep pembinaan hukum menurut Mochtar Kusumaatmadja di antaranya yaitu :}

1. Hukum tidak meliputi asas dan kaidah yang mengatur kehidupan manusia di masyarakat termasuk lembaga dan proses di dalam mewujudkan kaedah itu di dalam kenyataan.

2. Hukum adalah keseluruhan kaedah dan asas yang mengatur kehidupan manusia di masyarakat, termasuk lembaga dan proses di dalam mewujudkan berlakunya hukum.

Penjelasan :

- Pada pengertian yang pertama kata kaedah mengandung makna yaitu Undangundang Normatif Positivisme.

- Kata asas dan kaedah menggambarkan hukum sebagai gejala normative (hukum alam).

- Kata lembaga dan proses menggambarkan hukum sebagai gejala sosial (sociological yurispudence).

\footnotetext{
${ }^{15}$ Abdul Manan, Aspek-Aspek Pengubah Hukum, (Jakarta: Kencana Persada Media, 2005), h. 98.
} 
- Gejala sosial adalah gejala-gejala yang terdapat di masyarakat yang berkaitan dengan kebutuhan pokok manusia (kemakmuran, kekuasaan, kedudukan, keadilan, kepastian, kerukunan, keserasian, kehormatan, kegunaan dan kebahagiaan, dan sebagainya).

“Menurut penulis bahwa pernyataan Mochtar Kusumaatmadja tersebut di atas, bahwa hukum akan berjalan dengan baik dan benar, jika adanya kaidah hukum yang meliputi 3 unsur, yaitu unsur yuridis, sosiologis, dan filosofis".

Ketiga unsur tersebut saling berkaitan satu sama lain, karena jika salah satunya pincang, maka pincanglah implementasi hukum, dan sebaliknya jika ketiga unsur tersebut ada pada kaidah hukum yang dibuat, dan berjalan dengan baik dan benar secara berkeinambungan, maka implementasi hukum terhadapa perilaku-perilaku masyarakat akan terwujud secara baik dan benar pula.

Unsur yuridis memiliki arti yang sangat mendalam. Bahwa hukum yang dibuat tidak boleh bertentangan dengan hukum di atasnya. Baik hukum Tuhan maupun hukum manusia. Menurut teori stufenbau oleh Hans Kelsen bahwa hukum di bawahnya tidak boleh bertentangan dengan hukum di atas. Contoh, yurisprudensi (putusan-putusan hakim di badan peradilan) tidak boleh bertentangan dengan undang-undang yang kedudukan undangundang lebih tinggi daripada yurusprudensi. Juga undang-undang tidak boleh bertentangan dengan konstitusi (undang-undang dasar). Juga undang-undang dasar tidak boleh bertentangan dengan di atasnya, yaitu Pancasila. Pancasila adalah sebuah ideologi bagi sebuah Negara yang berdaulat, yaitu Indonesia. Menurut penulis sebagai dosen di mata kuliah sosiologi hokum, maka penulis berani berpendapat, bahwa Pancasila benar-benar tidak bertentangan dengan al-Quran dan Hadis nabi.

Pancasila dengan sila pertama adalah Ketuhanan Yang Maha Esa, dan seterusnya sila kedua, ketiga, keempat, dan kelima. Semua lima sila di Pancasila adalah cocok dengan tradisi nabi dan sahabat serta para ulama yang menjunjung tinggi kepercayaan terhadap Tuhan Yang Maha Esa, juga keadilan sosial bagi semua unsur, juga persatuan dan kesatuan bagi semua unsur, juga musyawarah (wa amruhum syuro bainahum) ${ }^{16}$. Jadi, Pancasila sebagai ideologi bagi masyarakat Indonesia yang majemuk adalah sebuah keputusan bersama para pemimpin Indonesia yang dipelopori oleh Ir. Soekarno dan Muhammad Hatta serta dibantu oleh para pemimpin lainya di jaman sebelum diproklamirkannya kemerdekaan Negara

${ }^{16}$ Zainuddin Ali, Ilmu Hukum: Pancasila dan Kewarganegaraan di Indonesia, (Palu: Yayasan Masyarakat Indonesia Baru, 2002), h. 52. 
Indonesia pada tanggal 17 Agustus 1945. Satu hari setelah kemerdekaan Indonesia tepatnya pada tanggal 18 Agustus 1945 di gedung Pegangsaan Timur no. 56 Jakarta pada hari Jumat pkl. 16.00 WIB, maka disahkanlah Undang-Undang Dasar 1945 oleh Ir. Soekarno. Oleh karena itu, undang-undang dasar republik Indonesia disebut Undang-Undang Dasar 1945 (UUD 45).

Allah tidak memaksa suatu kaum untuk beriman kepada-Nya, namun Allah menyuruh manusia secara utuh untuk berbuat adil terhadap siapapun ${ }^{17}$. Ini adalah inti ajaran Islam secara universal. Lakum dinukum waliyadin ${ }^{18}$ (bagimu agamamu). Laa ikroha fid din (tidak ada paksaan dalam Beragama). Ini adalah firman Allah yang jelas dan universal. Jadi, manusia baik pemimpin maupun yang dipimpin harus saling memberikan yang terbaik terhadap satu sama lainnya. Hukum harus dipublikasikan dan diterapkan di dalam situasai apapun dan kapanpun, dan semua orang sama di depan hukum (equality before the law).

Indonesia adalah Negara yang berdaulat sejak kemerdekaan Republik Indonesia. Di dalam GBHN 1973 : Hukum tidak boleh menghambat proses pembangunan yang merupakan suatu proses yang menyangkut seluruh aspek-aspek kehidupan manusia dan di dalam GBHN 1978 : Hukum dapat berfungsi sebagai sarana pembaharuan ${ }^{19}$.

"Hukum dibuat untuk merubah masyarakat dari kebodohan menuju kecerdasan, kemiskinan menuju kejayaan, pertengkaran menuju perdamaian, dan seterusnya. Demikian hukum dibuat".

GBHN 1983 : Hukum sebagai sarana rekayasa masyarakat (social engineering).

Contoh: Di dalam Undang-Undang Hak Cipta, di mana hal tersebut merubah pemikiran masyarakat industri menjadi masyarakat informasi.

Filsafat dan hukum merupakan dua materi yang harus diketahui oleh pemerhati di bidang hukum, juga mahasiswa hukum yang mempelajari sosiologi hukum harus memahami kedua materi tersebut.

\section{Filsafat Hukum}

\footnotetext{
${ }^{17}$ QS. Al-Ahzab: 70.

${ }^{18}$ QS, Al-Kafirun: 6.

${ }^{19}$ Zainuddin Ali, Ilmu Hukum ..., h. 78.
} 
Di dalam filsafat hukum terdapat beberapa aliran yang mendorong tumbuh dan berkembangnya sosilogi hukum ${ }^{20}$, di antaranya yaitu

1. Mazhab sejarah, tokohnya Carl Von Savigny (hukum itu tidak dibuat, akan tetapi tumbuh dan berkembang bersama-sama masyarakat). Hal tersebut merupakan perwujudan dari kesadaran hukum masyarakat, perkembangan hukum sejalan dengan perkembangan masyarakat sederhana ke masyarakat modern.

2. Mazhab utility, tokohnya Jeremy Bentham (hukum itu harus bermanfaat bagi masyarakat guna mencapai hidup bahagia). Di mana manusia bertindak untuk memperbanyak kebahagiaan dan mengurangi penderitaan dan pembentuk hukum harus membentuk hukum yang adil bagi segenap warga-warga masyarakat secara individual). Rudolph von Ihering (social utilitarianism yaitu hukum merupakan suatu alat bagi masyarakat untuk mencapai tujuan)

3. Aliran sociological jurisprudence, tokohnya Eugen Ehrlich (hukum yang dibuat harus sesuai dengan hukum yang hidup di dalam masyarakat atau living law).

4. Aliran pragmatical legal realism, tokohnya Roscoe Pound (law as a tool of social engineering), Karl Lewellyn, Jerome Frank, Justice Oliver (hakim-hakim tidak hanya menemukan huhum akan tetapi bahkan membentuk hukum).

\section{Ilmu hukum}

Yang mendukung ilmu soiologi hukum adalah ilmu hukum yang menganggap bahwa hukum itu adalah gejala sosial.

\section{Sosiologi yang berorientasi di bidang hukum}

Menurut Emile Durkhaim mengungkapkan bahwa di dalam masyarakat selalu ada solidaritas sosial yang meliputi :

- Solidaritas sosial mekanis yaitu terdapat di masyarakat sederhana di mana kaidah hukumnya bersifat represif (yang diasosiasikan ke dalam hukum pidana).

- Solidaritas sosial organis yaitu terdapat di masyarakat modern di mana kaidah hukumnya bersifat restitutif (yang diasosiasikan ke dalam hukum perdata).

\footnotetext{
${ }^{20}$ Azmi Siradjuddin, Sosiologi ..., h. 39.
} 
Solidaritas mekanis merupakan sebuah keseragaman bagi masyarakat sederhana di mana pun mereka berada, terutama masyarakat suku pedalaman. Hukum berjalan dengan hukuman langsung bagi pelanggarnya. Contoh, suku Amazon di Amerika Selatan, jika seorang wanita melakukan perbuatan cabul dengan orang asing, maka kepala suku akan memberikan hukum langsung tanpa proses pertanyaan (pengadilan) dengan cara membunuh wanita terebut sesuai dosanya. Namun, solidaritas organis di masyarakat modern sudah terjadi proses berpikir secara keilmuan, di mana pelanggar hukum (law breakers) diperoses dengan mekanisme badan peradilan.

\section{Kedudukan dan Letak Sosiologi Hukum di bidang Ilmu Pengetahuan}

Sosiologi adalah merupakan cabang dari ilmu hukum

Menurut Soerjono Soekanto ${ }^{21}$ sosiologi hukum adalah cabang ilmu hukum yaitu ilmu hukum tentang kenyataan. Pendapat ini didasarkan pada pengertian tentang disiplin, yaitu suatu ajaran tentang kenyataan yang meliputi :

- Disiplin analitis : sosiologi, psikologi.

- Disiplin hukum (perspektif): ilmu hukum normative dan kenyataan (ilmu hukum kenyataan, sosiologi hukum, antropologi hokum.

Hukum secara sosiologi merupakan suatu lembaga kemasyarakatan yang diartikan sebagai suatu himpunan nilai nilai, kaidah kaidah dari pola perikelakuan yang berkisar pada kebutuhan kebutuhan pokok manusia dan saling mempengaruhi. Sosiologi hukum merupakan refleksi dari inti pemikiran-pemikiran tersebut.

- Aliran hukum alam (Aristoteles, Aquinas, Grotius)

- Hukum dan moral

- Keepastian hukum dan keadilan sebagai tujuan dari sistem hukum

- Madzhab formalisme (austin, kelsen)

- Logika hukum

${ }^{21}$ Soerjono Soekanto, Suatu Tinjauan Sosiologi Hukum Terhadap Masalah-Masalah Sosial, (Bandung: Alumni, 1982), h. 58. 
- Fungsi keajegan dari pada hukum

- Peranan formal dari petugas hukum

- Mazhab kebudayaan dan sejarah (Carl von savigny, Maine)

- Kerangka budaya dari hukum, termasuk hubungan antara hukum dan sistem nilai nilai

- Hukum dan perubahan perubahan social

- Aliran utilitarianisme dan sociological jurisprudence (J. Bentham, Jhering, Eurlich, Pound)

- Konsekuensi konsekuensi sosial dari hukum (w. Friedman )

- Penggunaan yang tidak wajar dari pembentuk undang undang

- Klasifikasi tujuan tujuan mahluk hidup dan tujuan tujuan social

- Aliran sociological jurisprudence (Eurlich, Pound) dan legal realism (holmes, llewellyn, frank)

- Hukum sebagai mekanisme pengendalian sosial

- Faktor faktor politis dan kepentingan dalam hukum, termasuk hukum dan stratifikasi sosial

- Hubungan antara kenyataan hukum dengan hukum yang tertulis

- Hukum dan kebijaksanaan kebijaksanaan hukum

- Segi perikemanusiaan dari hukum

- Studi tentang keputusan keputusan pengadilan dan pola pola perikelakuannya

Sosiologi Hukum Adalah Merupakan Cabang Sosiologi

\section{Sosiologi Oreintasi Hukum}

Menurut Satjipto Rahardjo22 mengungkapkan bahwa sosiologi hukum adalah merupakan cabang sosiologi yaitu sosiologi bidang hokum/sosiologi orentasi hukum.

Sosiologi Orentasi Hukum, di mana perilaku masyarakat harus sesuai dengan perilaku/aturan hokum. Contoh, seorang pengendara kendaraan harus membawa lengkap

\footnotetext{
${ }^{22}$ Satjipto Rahardjo, Hukum dalam ..., h. 78.
} 
surat-surat kendaraan. Seorang muslim harus puasa ramadhon dan tidak makan di depan yang terbuka.

Ilmu yang mempelajari fenomena hukum, dari sisinya tersebut di bawah ini disampaikan beberapa karakteristik dari studi hukum secara sosiologis:

- Memberikan penjelasan mengenai praktik praktik hukum baik oleh para penegak hukum maupun masyarakat. Apabila praktik praktik tersebut dibedakan ke dalam pembuatan peraturan perundang undangan, penerapan dan pengadilan, maka sosiologi hukum juga mempelajari, bagaimana praktik yang terjadi pada masing masing kegiatan hukum tersebut.

- Senantiasa menguji keabsahan empiris dari suatu peraturan atau pernyataan hukum, apabila hal itu dirumuskan dalam suatu pertanyaan, pertanyaan itu adalah : bagaimanakah dengan kenyataannya peraturan tersebut?, apakah kenyataan memang seperti tertera pada bunyi peraturan? Terdapat suatu perbedaan yang besar antara pendekatan tradisional yang normative dan pendekatan sosiologis yaitu bahwa yang pertama menerima saja apa yang tertera pada aturan hukum, sedang yang kedua senantiasa menguji dengan data empiris.

- Berbeda dengan ilmu hukum, sosiologi hukum tidak melakukan penilaian terhadap hukum. Perilaku yang mentaati hukum dan yang menyimpang dari hukum sama sama merupakan objek pengamatan yang setaraf. Sosiologi hukum tidak menilai yang satu lebih dari yang lain. Perhatian yang utama hanyalah pada memberikan penjelasan terhadap penjelasan terhadap objek yang dipelajari. Sosiologi hukum tidak memberikan penilaian, melainkan mendekati hukum dari segi objektivitas semata dan bertujuan untuk memberikan penjelasan terhadap fenomena hukum yang nyata.

Pernyataan tersebut di atas memberikan isarat kepada komponen-komponen masyarakat bahwa perilaku hokum manusia baik individu maupun kelompok merupakan refleksi pemaham mereka di bidang hokum sendiri dan pengalaman mereka di dalam pergaulan baik pergaulan akademis maupun pergaulan masyarakat. 


\section{Konsep-Konsep Sosiologi Hukum}

\section{Hukum Berfungsi Sebagai Sarana Social Control (Pengendalian Sosial)}

Hukum sebagai sosiol control : kepastian hukum, artinya Undang-Undang yang dilakukan benar-benar terlaksana oleh penguasa, penegak hukum. Fungsinya masalah penginterasian tampak menonjol, dengan terjadinya perubahan perubahan pada faktor tersebut di atas, hukum harus menjalankan usahanya sedemikian rupa sehingga konflik-konflik serta kepincangan- kepincangan yang mungkin timbul tidak mengganggu ketertiban serta produktivitas masyarakat ${ }^{23}$.

Pengendalian sosial adalah upaya untuk mewujudkan kondisi seimbang di dalam masyarakat, yang bertujuan terciptanya suatu keadaan yang serasi antara stabilitas dan perubahan di dalam masyarakat.

Maksudnya adalah hukum sebagai alat memelihara ketertiban dan pencapaian keadilan. Pengendalian sosial mencakup semua kekuatan-kekuatan yang menciptakan serta memelihara ikatan sosial. Hukum merupakan sarana pemaksa yang melindungi warga masyarakat dari perbuatan dan ancaman yang membahayakan dirinya dan harta bendanya.

\section{Hukum Berfungsi Sebagai Sarana Social Engineering}

Manusia adalah makhluk sosial. Di mana ada manusia di situ ada hukum (ubi societas $u b i$ ius). Hukum yang berarti aturan-aturan perilaku yang dapat diberlakukan/diterapkan untuk mengatur hubungan-hubungan manusia baik bubungan antara individu dan individu dan antara individu dengan kelompok baik dalam bentuk stratifikasi-stratifikasi maupun lembaga-lembaga sosial lainnya ${ }^{24}$.

Hukum dapat bersifat sosial engineering : merupakan fungsi hukum dalam pengertian konservatif, fungsi tersebut diperlukan dalam setiap masyarakat, termasuk dalam masyarakat yang sedang mengalami pergolakan dan pembangunan. Mencakup semua kekuatan yang menciptakan serta memelihara ikatan sosial yang menganut teori imperative tentang fungsi hukum ${ }^{25}$.

Hal ini dimaksudkan dalam rangka memperkenalkan lembaga-lembaga hukum modern untuk mengubah alam pikiran masyarakat yang selama ini tidak mengenalnya, sebagai

\footnotetext{
${ }^{23}$ Soerjono Seokanto, Suatu Tinjauan, ..., h. 62.

${ }^{24}$ Soerjono Soekanto, Sosiologi Hukum dalam Masyarakat, h. 13.

${ }^{25}$ Satjipto Rahardjo, Hukum dan Perubahan Sosial, (Bandung: Alumni, 1979), h. 81-82.
} 
konsekuensi Negara sedang membangun, yang kaitannya menuju modernisasi dalam meningkatkan taraf hidup masyarakat.

Maksudnya adalah hukum sebagai sarana pembaharuan dalam masyarakat. Hukum dapat berperan dalam mengubah pola pemikiran masyarakat dari pola pemikiran yang tradisional ke dalam pola pemikiran yang rasional/modern.

\section{Wibawa Hukum}

Melemahnya wibawa hukum menurut O. Notohamidjoyo, di antaranya karena hukum tidak memperoleh dukungan yang semestinya dari norma-norma sosial bukan hukum, normanorma hukum belum sesuai dengan norma-norma sosial yang bukan hukum, tidak ada kesadaran hukum dan kesadaran norma yang semestinya, pejabat-pejabat hukum yang tidak sadar akan kewajibannya untuk memelihara hukum Negara, adanya kekuasaan dan wewenang, ada paradigma hubungan timbal balik antara gejala sosial lainnya dengan hukum²6. Dalam artian sebagai berikut :

- Hukum tidak memperoleh dukungan yang semestinya dari norma norma sosial bukan hukum, melemahnya value sistem dalam masyarakat pada umumnya sebagai akibat dari modernisasi.

- Norma norma hukum tidak batau belum sesuai dengan norma norma sosial yang bukan hukum, hukum yang dibentuk terlalu progresif sehingga dirasakan sebagai norma norma asing bagi rakyat.

- Tidak ada kesadaran hukum dan kesadaran norma yang semestinya.

- Pejabat pejabat hukum tidak sadar akan kewajibannya yang mulia untuk memelihara hukum negara, lalu mengkorupsikan, merusak hukum negara itu.

- Pemerintah pusat dan daerah berusaha membongkar hukum yang berlaku untuk madsud maksud tertentu. Dapat terjadi bahwa pemerintah yang seharusnya mendukung hukum sebagai kewajibannya, malah menghianati hukum yang berlaku.

\section{Ciri-ciri Sistem Hukum Modern}

\footnotetext{
${ }^{26}$ Satjipto Rahardjo, Ibid. h.34.
} 
Sistem hukum yang modern haruslah merupakan hukum yang baik, dalam arti hukum tersebut harus mencerminkan rasa keadilan bagi para pihak yang terlibat/diatur oleh hukum tersebut. Hukum tersebut harus sesuai dengan kondisi masyarakat yang diaturnya. Hukum tersebut harus dibuat sesuai dengan prosedur yang ditentukan. Hukum yang baik harus dapat dimengerti atau dipahami oleh para pihak yang diaturnya ${ }^{27}$.

Ciri ciri hukum modern :

- Terdiri dari peraturan yang isi dan pelaksanaannya seragam

- Sistem hukum yang transaksional dimana hak dan kewajiban dalam perjanjian tidak memandang usia, kelas, agama dan jenis kelamin

- Bersifat universal dan dilaksanakan secara umum

- Adanya hirarkis yang tegas

- Melaksanakan hukum sesuai dengan prosedur

- Rasional

- Dilaksanakan oleh orang yang berpengalaman

- Spesialisasi dan diadakan penghubung diantara bagian bagian

- Hukum mudah berubah sesuai dengan perkembangan masyarakat

- Penegak hukum dan lembaga pelaksana hukum adalah lembaga kenegaraan, artinya negara memonopoli kekuasaan

- Perbedaan yang tegas diantara 3 lembaga negara (eksekutif - legislative - yudicatif)

Ciri manusia modern :

- Rasional

- Jujur

- Tepat waktu

\footnotetext{
${ }^{27}$ Soerjono Soekanto, beberapa Permasalahan Hukum dalam Kerangka Pembangunan di Indonesia, (Jakarta: UI Press, 1983), h. 12.
} 
- Efisien

- rientasi ke masa depan

- Tidak status symbol (gengsi)

\section{Fenomena Hukum Yang Tumpul keatas dan Tajam Kebawah.}

Hingga saat ini banyak pelaku kejahatan kelas atas atau yang disebut kejahatan Kerah Putih (White Colour Crime) yang dihukum sangat ringan bahkan tidak sedikit yang divonis bebas, karena mereka memegang kekuasaan dan wewenang yang dapat mengintervensi para penegak hukum, hal ini berakibat bahwa mereka yang berstrata tinggi seolah kebal hukum dan sebaliknya hukum hanya dipergunakan untuk mereka yang berstrata rendah. Contoh, kasus Budi Gunawan yang menjadi tersangka oleh KPK (Komisi Pemberantasan Korupsi), namun Budi Gunawan lolos oleh jeratan hukum setelah mengajukan pra peradilan di pengadilan. Kasus yang sedang bergulir di bulan Oktober 2017, yaitu Setya Novanto Ketua DPR dan Ketua Partai Golkar setelah mengajukan pra peradilan di pengadilan, Setya Novanto memenangkan perkara dan beliau bebas dari jeratan hukum oleh KPK. Bulan November 2017, KPK menetapkan Setya Novanto sebagai tersangka untuk kedua kalinya, dan melalui pengacaranya mengajukan praperadilan kedua yang akan disidangkan di pengadilan Jakarta Selatan pada tanggal 30 November 2017. Banyak cerita kasus-kasus hukum yang pelakunya dari kalangan kerah putih terbebas dari jeratan hukum. Inilah perlunya penerapan hukum dan pemberdayaan hukum terhadap perilaku masyarakat khususnya perilaku hukum oleh kalangan pejabat, pengusaha besar, dan anak pejabat.

\section{Efektifitas Hukum dan Peranan Sanksi}

Merupakan naskah yang berisikan sorotan sosial hukum terhadap peranan sanksi dalam proses efektivikasi hukum. Efektivikasi hukum merupakan proses yang bertujuan agar supaya hukum berlaku efektif. Keadaan tersebut dapat ditinjau atas dasar beberapa tolok ukur efektivitas. Menurut Suryono efektifitas dari hukum di antaranya :

a. Hukum itu harus baik:

- Secara sosiologis (dapat diterima oleh masyarakat); 
- Secara yuridis (keseluruhan hukum tertulis yang mengatur bidang bidang hukum tertentu harus sinkron);

- Secara filosofis;

b. Penegak hukumnya harus baik, dalam artian betul betul telah melaksanakan tugas dan kewajibannya sebagaimana digariskan oleh hukum yang berlaku.

c. Fasilitas tersedia yang mendukung dalam proses penegakan hukumnya.

d. Kesadaran hukum masyarakat.

Masyarakat yang baik adalah masyarakat yang memiliki kesadaran akan hukum, namu ada syarat yang harus dipenuhi agar hukum itu dapat berjalan dengan baik. Adapun syarat agar masyarakat memiliki kesadaran hukum antara lain :

- $\quad$ Tahu hukum (law awareness);

- Rasa hormat terhadap hukum (legal attitude);

- Paham akan isinya (law acqium tance);

- Taat tanpa dipaksa (legal behaviore).

e. Budaya hukum masyarakat

Perlu ada syarat yang tersirat yaitu pandangan Ruth Benedict tentang adanya budaya malu, dan budaya rasa bersalah bilamana seseorang melakukan pelanggaran terhadap hukum hukum yang berlaku²8

Cara mengatasinya :

1. Eksekutif harus banyak membentuk hukum dan selalu mengupdate;

2. Para penegak hukumnya harus betul betul menjalankan tugas kewajiban sesuai dengan hukum hukum yang berlaku dan tidak boleh pandang bulu;

3. Lembaga mpr sesuai dengan ketentuan uud 1945 melakukan pengawan terhadap kerja lembaga lembaga negara.

\section{Kesadaran Hukum dan Kepatuhan Hukum}

Sadar : dari hati nurani

\footnotetext{
${ }^{28}$ Soerjono Soekanto, Ibid. h. 67-69.
} 
Patuh : Takut sanksi yang negatif

Kesadaran hukum merupakan konsepsi abstrak didalam diri manusia, tentang keserasian antara ketertiban dan ketentraman yang dikehendaki atau sepantasnya. Kesadaran hukum sering dikaitkan dengan pentaatan hukum, pembentukan hukum, dan efektivitas hukum. Kesadaran hukum merupakan kesadaran/nilai-nilai yang terdapat dalam manusia tentang hukum yang ada atau tentang hukum yang diharapkan²9.

Kesadaran hukum berkaitan dengan kepatuhan hukum, hal yang membedakannya yaitu dalam kepatuhan hukum ada rasa takut akan sanksi.

- kesadaran : tidak ada sanksi, merupakan perumusan dari kalangan hukum mengenai penilaian tersebut, yang telah dilakukan secara ilmiah, nilai nilai yang terdapat dalam manusia tentang hukum yang ada atau tentang hukum yang diharapkan ada.

Indicator kesadaran hukum :

1. pengetahuan hukum

2. pemahaman hukum

3. sikap hukum

4. pola perilaku hukum

- kepatuhan : ada sanksi positif dan negative, ketaatan merupakan variable tergantung, ketaatan hukum tersebut didasarkan kepada kepuasan diperoleh dengannn dukungan sosial

Faktor yang menyebabkan masyarakat mematuhi hukum :

- Compliance, yaitu kepatuhan yang didasarkan pada harapan akan suatu imbalan dan usaha untuk menghidarkan diri dari hukuman yang mungkin dikenakan apabila seseorang melanggar ketentuan hukum. Adanya pengawasan yang ketat terhadap kaidah hukum tersebut.

- Identification, terjadi bila kepatuhan terhadap kaidah hukum ada bukan karena nilai intrinsiknya, akan tetapi agar ke anggotaan kelompok tetap terjaga serta ada hubungan

\footnotetext{
${ }^{29}$ Satjipto Rahardjo, Hukum dan Perubahan, ... , (Bandung: Alumni, 1979). h. 29.
} 
baik dengn mereka yang diberi wewenang untuk menerapkan kaidah kaidah hukum tersebut

- Internalization, seseroang mematuhi kaidah kaidah hukum dikarenakan secara intrinsic kepatuhan tadi mempunyai imbalan. Isinya sesuai dengan nilai nilainya dari pribadi yang bersangkutan.

- Kepentingan-kepentingan para warga yang terjamin oleh wadah hukum yang ada

\section{Faktor Penghambat Perkembangan Sosiologi Hukum}

Adapun yang menjadi penghambat dari berkembangnya ilmu sosiologi hukum, adalah sebagai berikut:

- Tidak samanya bahasa kerangka pemikiran yang digunakan antara ahli sosiologi dengan ahli hukum

- Sulitnya bagi para sosiologi hukum untuk menempatkan dirinya dialam yang normatif

- Pada umumnya para sosiolog dengan begitu saja menerima pendapat bahwa hukum merupakan himpunan peraturan-peraturan yang statis.

- Kadangkala seorang sosiolog merasakan adanya kesulitan-kesulitan untuk menguasai keseluruhan data tentang hukum yang demikian banyaknya yang pernah dihasilkan oleh beberapa generasi ahli-ahli hukum

- Para ahli hukum lebih memusatkan perhatian pada kejadian-kejadian konkret sedangkan para sosiolog menganggap kejadian konkret tersebut sebagai refleksi dari gejala-gajala atau kecenderungan-kecenderungan umum

Cabang Sosiologi Hukum (Soeryono)

1. Paradigma (the genetic sociology of law)

- Sampai sejauh mana hukum dapat mempengaruhi tingkah laku manusia.

- $\quad$ Bagaimanakah cara yang paling efektif dari hukum dalam pembentukan perilaku masyarakat.

- $\quad$ Apakah hukum yang membentuk perilaku atau sebaliknya.

Contoh : UU Nomor 1 tahun 1974 (kawin muda), UU Narkotika (orang tua diajak berpikir rational, petani diajak berpikir rational)

1. Soiologi Teoritis dan Praktis 
Sosiologi praktis

- $\quad$ Sosiologi teoritis yaitu meneliti dasar sosial dari hukum positif tertulis

- $\quad$ Mempelajari tentang tumbuh dan berkembangnya hukum positif tertulis

- Lebih ditekankan pada penelitian bertujuan untuk mneghasilkan generalisasi atau hipotesa

Contoh : UU bagi hasil

Sosiologi praktis

- Sosiologi praktis yaitu meneliti efektifitas dari hukum dalam masyarakat

- Dapat menganalisa konstruksi terhadap efektifitas hukum dalam masyarakat

Contoh : Kasus pungutan liar, UU tentang pungutan tidak jalan

Hukum-gejala social yaitu UU Penanaman Modal

Hukum-politik yaitu UU Pemilu

Hukum-budaya yaitu UU Peerguruan Tinggi

2. Soiologis Empiris

Yaitu hipotesis dicocokan dengan keadaan yang sebenarnya atau melihat hukum yang erat kaitannya dengan gejala sosial lainnya.

Contoh : Undang-Undang Nomor 1 Tahun1974 Pasal 2

UU Narkotika

UU Lingkunga hidup

Perihal perspektif dari pada sosiologi hukum, maka secara umum ada dua pendapat utama, yaitu sebagai berikut :

1. Pendapat-pendapat yang menyatakan bahwa kepada sosiologi hukum harus diberikan suatu fungsi yang global, artinya sosiologi hukum harus menghasilkan suatu sintesa antara hukum sebagai sarana organisasi sosial dan hukum sebagai 
sarana dari keadilan. Didalam fungsi tersebut maka hukum dapat memperoleh bantuan yang tidak kecil dari sosiologi hukum didalam mengidentifikasi konteks sosial dimana hukum tadi diharapkan berfungsi.

2. Pendapat-pendapat lain menyatakan bahwa kegunaan sosiologi hukum adalah justru dalam bidang penerangan dan pengkaidahan, dimana sosiologi hukum dapat mengungkapkan data tentang keajegan-keajegan mana didalam masyarakat yang menuju pada pembentukan hukum (baik melalui keputusan penguasa maupun melalui ketetapan bersama dari para warga masyarakat terutama yang menyangkut hukum fakultatif).

Menurut perspektif sosiologi hukum tersebut maka dapatlah dikatakan bahwa kegunaan sosiologi hukum adalah sebagai berikut :

- Sosiologi hukum berguna untuk memberikan kemampuan-kemampuan bagi pemahaman terhadap hukum di dalam konteks sosial.

- Penguasaan konsep-konsep sosiologi hukum dapat memberikan kemampuan kemampuan untuk mengadakan analisis terhadap efektivitas hukum dalam masyarakat baik sebagai sarana untuk mengubah masyarakat maupun sarana untuk mengatur interaksi sosial agar mencapai keadaan-keadaan sosial tertentu.

- Sosiologi hukum memberikan kemungkinan-kemungkinan serta kemampuan untuk mengadakan evaluasi terhadap efektifitas hukum di dalam masyarakat.

\section{Simpulan}

Hukum harus diterapkan kepada setiap manusia atau kelompok di mana pun dan kapan pun mereka berada. Hukum ada yang wajib dipatuhi (compulsory/memaksa) dan ada yang bersifat mengikat (sunnah). Hukum adalah sebagai pedoman bagi manusia di sebuah Negara berdaulat. Hukum memberikan sanksi (sanction) kepada mereka yang melanggarnya baik berupa perbuatan perdata maupun pidana. Mereka yang menaati hukum baik hukum Tuhan maupun hukum Negara berupa undang-undang, maka mereka akan mendapat reward (penghargaan). Oleh karena itu, hukum harus dilestarikan terus menerus, hukum harus diingatkan terus kepada lapisan masyarakat, dengan harapan hukum dapat memberikan kenyamanan, ketenteraman, kedamaian, kepastian, kemajuan dan kemakmuran/kesejahteraan. 
Sesuai tujuan hukum adalah, sebagai social control, social engineering, social dispute. Fungsi hukum itu sendiri adalah sebagai instrument ketertiban, keadilan dan perubahan sosial. Dengan hukum manusia akan mendapatkan kebahagian baik di dunia maupun di akhirat. Ingat di mana ada manusia di situ ada hokum (ubi society ubi ius). Hukum selalu berdampingan kepada setiap individu dan kelompok di mana pun dan kapan pun mereka hidup sampai datangnya kematian/ajal.

\section{DAFTAR PUSTAKA}

Amin, S.M., Pembaharuan Hukum di Indonesia, In Memoriam Prof. Dr. Hazairin, UI Press, Cet. I, Jakarta, 1976.

A.Harjono, dkk, Pembaharuan Hukum Islam di Indonesia, In Memorian Prof. Mr. Dr. Hazairin, Jakarta: UI Press, 1976.

Ali, Zainudin. Ilmu Hukum: Pancasila dan Kewarganegaraan di Indonesia. Palu : Yayasan Masyarakat Indonesia Baru, 2002.

.Imu Hukum dalam Masyarakat Indonesia. Palu : Yayasan Masyarakat Indonesia Baru, 2001.

Atep Adya Brata. Dasar-dasar Pelayanan Prima. Jakarta: Gramedia, 2003.

A.W. Khallaf, Sumber-suber Hukum Islam, Bandung: Risalah, 1984.

Biro Pusat Statistik, Penduduk Indonesia Menurut Propinsi, Seri L No. 3, Tabel 6. Cf. Tabel 9.

Brugman, J. “Snouck Hurgronje's Study Of Islamic Law." In Leiden Orintal Connections 18501940, ed. Willem Ottorspeer, 82-93. Leiden: E.J. Brill, 1969.

Bustanul Arifin, “Pelaksanaan Hukum Islam di Indonesia”, Al-Mizan, Nomor 3 Tahun1983.

Joseph S. Roucek \& Roland L. Warren. Pengantar Sosiologi. Jakarta: Bina Aksara, 1984.

Kusumadi Pudjosewojo. Pedoman Pelajaran Tata Hukum Indonesia. Jakarta : P.D. Aksara, 1971.

Mariun. Asas-asas Ilmu Pemerintahan. Seksi Penerbitan Litbang Fakultas Sosial dan Politik UGM. Yogyakarta, 1979.

Masjfuk Zuhdi, Ijtihad dan Problematikanya dalam Memasuki Abad XV Hijriyah, Surabaya, Bina Ilmu,

1981.

M.A. Mudzhar, Social History Approach To Islamic Law, Jurnal IAIN al-Jamiah No. 61. Yogyakarta. 
M.B. Hooker, Islamic Law in South-East Asia, Singapore: Oxpord University Press, 1984.

M. Hasbi Ash-Shiddieqy, Falsafah Hukum Islam, Jakarta, Bulan Bintang, 1975.

Moch. Koesnoe, Perbandingan antara Hukum Islam, Hukum Eropa dan Hukum Adat. Seminar Pembinaan Kurikulum Hukum Islam di Perguruan Tinggi, Badan Kerjasama PTIS, Kaliurang, 1980.

Muhammad Daud Ali, Kedudukan Hukum Islam dalam Sistem Hukum Indonesia, Jakarta, Yayasan Risalah, 1984.

Rahardjo, Satjipto. Hukum dan Perubahan Sosial. Bandung: Alumni, 1979.

------, Manfaat Telaah Sosial Terhadap I dala Amrah Muslimin, dkk., Beberapa Guru Besar Berbicara tentang Hukum u. Pendidikan Hukum (Kumpulan Pidato-Pidato Pengukuhan), Bandung: Alumni, 1981.

Soekanto, Soerjono, Suatu Tinjauan Sosiologi Hukum terhadap Masalah-Masalah Sosial, Bandung: Alumni, 1982.

Soekanto. Soerjono \& Mustafa Abdullah. Sosiologi Hukum dalam Masyarakat. Jakarta: Rajawali Press, 1982.

Soerjono Soekanto, beberapa Permasalahan Hukum dalam Kerangka Pembangunan di Indonesia, Jakarta: UI Press, 1983. 